\title{
An Analysis on Creative Thinking Skill on Algebra Materials of Students in Regular, Acceleration, and Olympiad Classes
}

\author{
Dwi Priyo Utomo \\ University of Muhammadiyah Malang \\ dwipuumm@yahoo.com
}

\begin{abstract}
This current study aimed at analyzing creative thinking skill in solving mathematical problems of students in regular, acceleration, and Olympiad classes. Qualitative research design was employed, by means of descriptive-explorative approach. The subjects of this study were students in regular, acceleration, and Olympiad classes in SMPN 1 Turen (Junior High School), Malang Regency, East Java, Indonesia. The instruments were test and interview to tap the students' creative thinking skill in solving mathematical problems. Data validity was done by means of triangulation. The data were analyzed by employing content and component analyses. This study has found that regarding creative thinking skill of the students of regular, acceleration, and Olympiad classes, the students have shown differences in three aspects of creative thinking skill, namely: fluency, flexibility, and originality. The students of regular class have been categorized into creative level, as they met the aspects of fluency and flexibility. The students of acceleration class have fallen into creative plus level, as they fulfilled the aspects of fluency and flexibility plus. The students of Olympiad class have shown to be highly creative, as they have met the aspects of fluency, flexibility, and originality.
\end{abstract}

Keywords: creative thinking skill, regular class, acceleration class, and Olympiad class.

\section{INTRODUCTION}

Mathematics teaching focuses more on the basic mathematical competences, and thus mathematics teachers put more attention to the basic mathematical concepts and procedures, as well as logical thinking skill so as to facilitate students to understand those concepts and procedures. Logical thinking skill is more emphasized than that of creative thinking skill. Creative thinking skill is less developed in mathematics classes. Logic has been the focus of discussion and creativity is perceived as less important in mathematics [7]. In fact, creative thinking skill is supposed to be developed as this is one of skills demanded in job fields [5].

Creative thinking should also result in various products. It should also create appropriate products. In addition, creative thinking leads to the gaining of new insights, approaches, perspectives, or ways to understand certain things [6]. Creative thinking refers to an ability to come up with various solutions that are new and open [4]. Creative thinking is original and ends up with variativeproducts [3].Create -
Putting elements together to form a novel, coherent whole or make an original product: (1) generating; (2) planning; and (3) producing [2]. Creative thinking offers new ways to see and complete certain tasks comprising three aspects: fluency, flexibility, and originality [1].

Regular class is the common class found in all schools. The time allotted for mathematics is around 5 hours per week, completed within 17 weeks per semester. Regular classes are conducted based upon the curriculum [10]. Olympiad class is preparing students for competing in a number of academicrelated Olympiads. The students are mostly excellently intelligent, and thus they are treated specially, different from regular and acceleration classes. Acceleration class is a class programmed to shorten students' study time[8]. The differences between acceleration and Olympiad classes are: (1) acceleration program allows students to pass the grade or complete their regular program in a shorter time; while Olympiad class prepares students for academic relatedcompetitions[9].

In one side, creative thinking skill is a pivotal aspect to develop through education for all; on the other side, there is one phenomenon of class categorization (regular, acceleration, and Olympiad) in schools that is interesting to investigate. This current study aimed at investigating how creative thinking skills vary among students across regular, acceleration, and Olympiad classes.

\section{METHOD}

\section{Research approach}

Qualitative research design was employed in this study, aiming at analyzing and describing students' creative thinking skill in mathematics in regular, acceleration, and Olympiad classes.

\section{Participant}

The subjects of this study were students in regular, acceleration, and Olympiad classes in SMPN 1 Turen (Junior High School), Malang Regency, East Java, Indonesia. The object of this study was creative thinking skill in solving mathematical problems. The subjects of the study were recruited from three types of classes: regular, acceleration, and Olympiad classes. There were in 6 students in total, comprising 2 students from regular class, 2 others from acceleration class, and the 2 others from Olympiad class.

\section{Data Collection and Analysis}

The validation of test items comprised the suitability between the test and the goal of learning (content validation) 
and the chances of the test to generate some answers that fulfill the aspect of mathematical creativity (construct validation). The in-depth interview was also conducted to tap the aspects of fluency, accuracy, and originality. Content analysis was conducted on the students' answers by basing on the criteria of accuracy, fluency, and originality. The creativity level of one class was compared to the creativity of the other class (component analysis).

\section{RESULT}

Below are the students' answers and interview results in regular class.

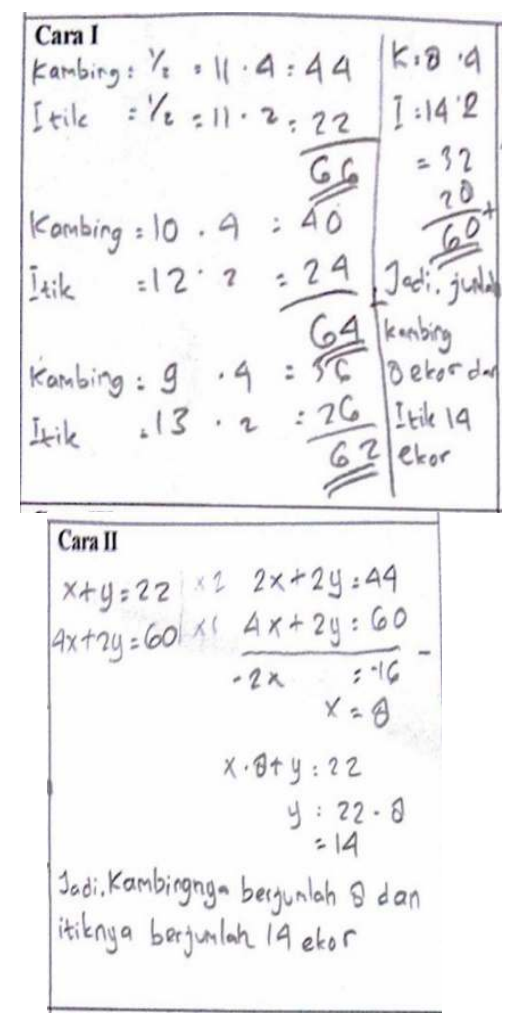

Figure 1. The Students' Answers and Interview Results in Regular Class

$\mathrm{R} \quad$ : Is there any other ways to solve the problem beside those two ways?

R-1 : No, there isn't. That's the only one.

$\mathrm{R}$ : How could you come up with the first way?

R-1 : Trial...wrong. There are too many feet. I subtracted the number of goats and added the number of ducks, until I got the fixed number.

R : Well. How could you come up with the second way?

R-1 : I used the terms $\mathrm{x}$ and $\mathrm{y} . \mathrm{x}$ referred to goats and $\mathrm{y}$ referred to ducks. Then, I made use of linear equation system. The 2 nd way was facilitated by the 1 st way to solve the problem.

Based on the analysis results, the students in regular class did not find any difficulty in implementing the proper ways to solve mathematical problems. However, it has been shown that the students have not come up with various problem solving ideas. The first way was trial-check. The second way was using algebra by means linear equation system. The first way was common among the students. The second way was taught by the teacher and used in class during explaining linear equation system. The students have not found the original way to solve the problems. The students did understand the mathematical problems and have the correct plans. They could create mathematical model and execute their plans to solve the problems. They could then recheck their answers.

Below are the students' answers and interview results in acceleration class.
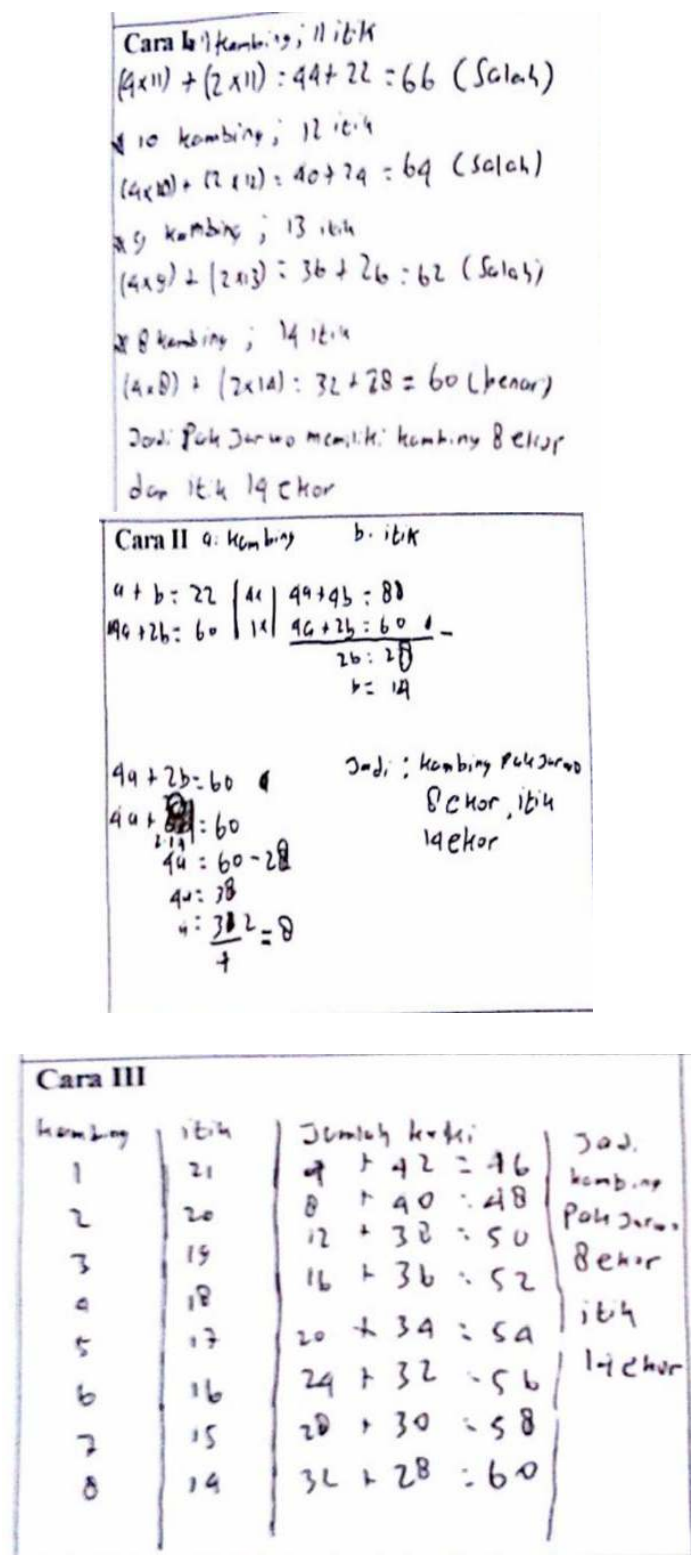

Figure 2. The Students' Answers and Interview Results in Acceleration Class

$\mathrm{R}$ : Is there any other ways to solve the problem beside those three ways?

A-1 : No, there isn't. I have used quite many.

$\mathrm{R} \quad$ : How could you come up with the first way?

A-1 : I was speculating. Half number of goats and half number of ducks; and it turned out to be wrong. 
Then, I subtracted the number of goats and added the number of ducks until I got 60 feet in total.

$\mathrm{R}$ : Well. How could you come up with the second way?

A-1 : I used the terms $a$ and $b$. a referred to goats and $b$ referred to ducks.

Then, I made use of linear equation system.

$\mathrm{R} \quad$ : Well. How could you come up with the third way?

A-1 : I used a table containing the number of goats and ducks. I started with 1 goat and 21 ducks. The number is supposed to be 22 . I checked the number of feet. I repeatedly did that until I got 60 feet in total.

$\mathrm{R} \quad$ : Did you learn that way in class?

A-1 : Yes, I did in statistics class and in textbook.

The students in acceleration class did not find any difficulty in implementing the proper way to solve the mathematical problems. The students had no problem in coming up with ideas to solve the mathematical items. They made use of three ways. First, they used guess-check; second, they used algebra equation model; and third, they drew a table to answer the mathematical problems. The first way was common among the students. The second way was taught by the teacher and used in class during explaining linear equation system. The third way was the systematic way by means of number 1-8 for the number of goats, and (22-n) for the number of ducks. $n$ represented the number of goats. The students multiplied the number of goats by 4 and the number of ducks by 2 . Then, they added the result of multiplication to reach 60 . The third way was more systematic that the first way; though solving by means of table has been commonly used by the teacher in class. Up to this stage, the students' originality has not been detected in acceleration class.

In solving the problems, the students in Olympiad class were capable of solving the problems, have shown their plans, and succeeded in executing their plans to solve the mathematical problems. The students could recheck their answers. Below are the students' answers and interview results in Olympiad class.

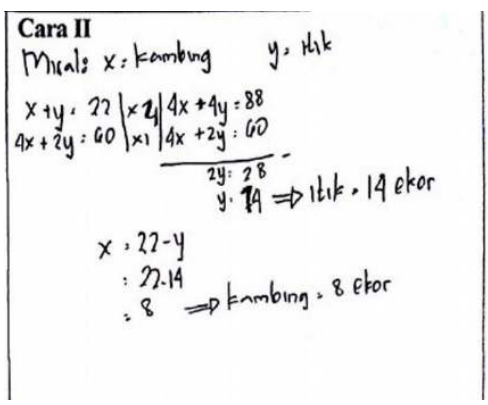
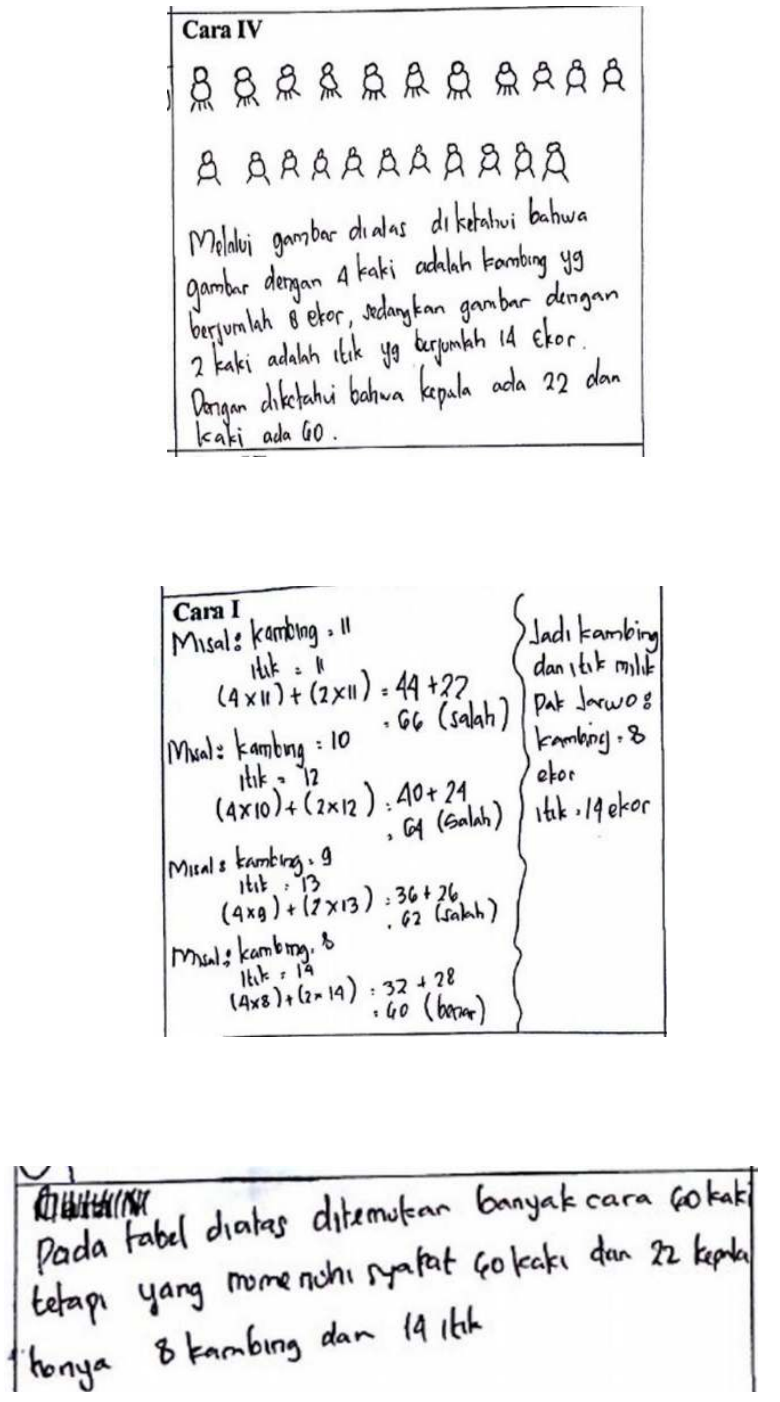

Figure 3. The Students' Answers and Interview Results in Olympiad Class

$\mathrm{R}$ : Is there any other ways to solve the problem you can think of?

O-1 : (silence)

$\mathrm{R} \quad$ : How could you come up with the first way?

O-1 : Half number of goats and half number of ducks; and after checking it

turned out to be wrong. Then, I subtracted the number of goats and

added the number of ducks until I got 60 feet in total.

$\mathrm{R}$ : Well. How could you come up with the second way?

O-1 : I used the terms $\mathrm{x}$ and $\mathrm{y} . \mathrm{x}$ referred to the number of goats and $b$ referred

to the number of ducks. Then, I made use of equation system.

$\mathrm{R} \quad$ : Well. How could you come up with the third way?

O-1 : I used a table. The row was for the number of goats (1 to 14) and column was for the number of ducks. I multiplied the number in the row by 4 and the number in the column by 2 . The result of the multiplication was put next to it. I gave a sign for the ones with the total of 60 . Then, I searched for the numbers in the row and column that were 22 in total. 
$\mathrm{R} \quad$ : Did you learn that way in class?

O-1 : Yes, I did in statistics class.

$\mathrm{R} \quad$ : Well. How could you come up with the fourth way?

$\mathrm{R} \quad$ : Did you learn that way in class?

O-1 : Never.

The students in Olympiad class could make use of the correct ways to solve the mathematical problems. They did not find any difficulty in generating ideas for solutions. They came up with four ways of solutions. First, they used guesscheck; second, they used algebra equation; third, they used a table with row-column; and fourth, they drew the pictures of animals. They started by drawing 22 animals. They gave two feet for each picture, so as to get 44 feet in total. Then they added two more feet for each animal until they got 60 feet in total. There were 8 pictures with 4 feet. They were the pictures of goats and the other 14 animals were ducks. The last way was original. The students found that by means of trial. It was never taught in class. In solving the problems, the students in Olympiad class were capable of solving the problems, have shown their plans, and succeeded in executing their plans to solve the mathematical problems. The students could then recheck their answers prior to submission.

\section{CONCLUSION}

This current study has arrived at the following conclusions: (1) The students of regular class have been categorized into creative level. In this level, the students met the aspects of fluency and flexibility; (2) The students of acceleration class have fallen into creative level. In this level, the students fulfilled the aspects of fluency and flexibility. As for flexibility, the students in acceleration class have performed better than those in regular class; and (3) The students of Olympiad class have shown to be highly creative. In this level, the students have met the aspects of fluency, flexibility, and originality. As for flexibility, the students in Olympiad class have performed better than those in regular class. They have succeeded in finding original ways to solve the given mathematical problems.

\section{REFERENCES}

[1] N. M. Anwar, "A Comparison of Creative Thinking Abilities of High and Low Achieve

[2] D. R. Krathwohl, "A Revision of Bloom's Taxonomy: An Overview. Theory Into Practice," Vol 41(4). College Education. The Ohio State University. 2002.

[3] S. Krulik \& J. Rudnick, Jesse A."Innovative Tasks To Improve Criticaland Creative Thinking Skills." Virginia: The National Council of teachers of Mathematics, Inc. 2000.

[4] Livne and Milgram. "Academic Versus Creative Abilities in Mathematics: Two Components of the Same Construct" [Online]. 2006.

[5] A. Mahmudi, "Mengukur Kemampuan Berpikir Kreatif Matematis." Makalah disajikan pada Konferensi Nasional Matematika XV UNIMA. Manado: Jurusan Pendidikan Matematika UNY. 2010.

[6] D. McGregor, "Developing Thinking Developing Learning." Poland: Open University Press. 2007.

[7] T. E. Y. Siswono, "Level of Student's Creative Thinking In Classroom Mathematics." Educational Research and Review, Vol. 6 (7), pp. 548-553. 2011.

[8] M. A. I. Sudrajat, "Studi komparasi antara hasil belajar siswa program akselerasi dengan siswa program olimpiade mata pelajaran Pendidikan Agama Islam SMAN 1 Semarang 2013/2014." http://eprints.walisongo.ac.id/1595/ dicek pada 16 oktober 2017. 2013.

[9] S. Tirtonegoro, "Anak Super Normal dan Program Pendidikannya," Jakarta: PT. Bumi Aksara. 2011.

[10] H. Widyastono H. "Sistem percepatan kelas bagi siswa yang memiliki kemampuan \& kecerdasan luar biasa."

http://www.depdiknas.go.id/jurnal/26/sistem_percepat an herry.htmdiakses 7 desember 2017. 2014. 